\title{
Strategi Guru Kelas Tinggi Sekolah Dasar dalam Menumbuhkan Disiplin Siswa melalui Manajemen Kelas
}

\author{
Yantoro, Issaura Sherly Pamela, Eka Purwati, Erni Ismaini \\ Universitas Jambi \\ Jalan Raya Jambi-Ma.Bulian KM. 15, Mendalo Indah, Jambi, Kode Pos 36351 \\ Email:yan.unja@gmail.com; issaurasherly@unja.ac.id; ekapalamarta98@gmail.com; \\ erniismainull98@gamil.com
}

Accepted: May 10, 2020

\begin{abstract}
The purpose of this research is to describe the strategies of elementary school high-class teachers in developing student discipline through classroom management. High class that will be used as research is in class IV. This research is a study that uses a qualitative approach to the type of qualitative phenomenological research. The subject of the study was a teacher in grade IV Mendalo Darat 211 / IX elementary school. Data collected through observation and interviews. The results of the study were in the form of texts about teacher strategies in fostering student discipline. Students of grade IV 211 I IX public elementary school Mendalo Darat have a good discipline attitude. One of the disciplines of students is reflected in the tasks done on time. The results of the study showed that good classroom management in class IV was a strategy implemented by the teacher in growing students' disciplinary attitudes. The strategy in question is how to maximize classroom wall clock, to remind the time remaining in doing the exercise. Seating strategies that are heterogeneous group seating. Strategies to play the voice intonation to attract the attention of students. Strategies to become good role models for students. The teacher's strategy for designing the class comfortably, so that students feel at home in the classroom. The conclusion of this study is that student discipline can be grown by the teacher's strategy, one of the strategies is to implement classroom management to the fullest.
\end{abstract}

Keywords: Teacher strategy, Discipline, Class Management

\begin{abstract}
Abstrak
Tujuan penelitian mendeskripsikan strategi guru kelas tinggi sekolah dasar dalam menumbuhkan disiplin peserta didik melalui manajemen kelas. Kelas tinggi yang akan dijadikan penelitian adalah pada kelas IV. Penelitian ini merupakan penelitian yang menggunakan pendekatan kualitatif dengan jenis penelitian kualitatif fenomenologi. Subjek penelitian adalah seorang guru kelas IV sekolah dasar negeri 211/IX Mendalo Darat. Data dikumpulkan melalui observasi dan wawancara. Hasil penelitian berupa teks tentang strategi guru dalam menumbuhkan disiplin peserta didik. Peserta didik kelas IV sekolah dasar negeri 211/IX Mendalo Darat memiliki sikap disiplin yang baik. Disiplin peserta didik salah satunya tercermin dari tugas yang dikerjakan tepat waktu. Hasil penelitian menunjukan bahwa manajemen kelas yang baik pada kelas IV merupakan strategi yang diterapkan oleh guru dalam
\end{abstract}


menumbuhkan sikap disiplin peserta didik. Strategi yang dimaksud adalah bagaimana memaksimalkan jam dinding kelas, untuk mengingatkan waktu yang tersisa dalam mengerjakan latihan. Strategi pengaturan tempat duduk yang berkelompok secara heterogen. Strategi memainkan intonasi suara untuk menarik perhatian peserta didik. Strategi menjadi tauladan yang baik untuk peserta didik. Strategi guru mendesain kelas dengan nyaman, sehingga peserta didik betah berada di dalam kelas. Kesimpulan dari penelitian ini adalah kedisiplinan peserta didik dapat ditumbuhkan dengan strategi guru, salah satu strateginya adalah dengan menerapkan manajemen kelas secara maksimal.

Kata Kunci: strategi guru, disiplin, manajemen kelas

\section{Pendahuluan}

Nilai karakter yang diterapkan pada pembelajaran kurikulum 2013, difungsikan sebagai perbaikan tujuan mutu pendidikan di Indonesia ${ }^{1}$. Mutu pendidikan di Indonesia harus selalu dilakukan perbaikan agar pendidikan di Indonesia semakin baik. Penerapan pendidikan karakter berarti membangun nilai-nilai karakter peserta didik, sehingga nantinya peserta didik mempunyai nilai karakter yang menjadi ciri khas dirinya dan mampu menerapkan nilainilai tersebut di hidupnya ${ }^{2}$. Karakter atau tujuan pembelajaran afektif menjadi tujuan utama pendidikan saat ini.

Pembentukan karakter paling utama dilakukan oleh keluarga. Namun, sekolah juga merupakan tempat yang cocok untuk menumbuhkan karakter peserta didik. Pendidikan karakter dapat diterapkan di jenjang sekolah dasar. Pendidikan karakter peserta didik jenjang sekolah dasar diterapkan dengan pendidikan holistik yang memfokuskan pada indikator religius, berpikir dan bersikap logis, kritis dan kreatif, jujur, inovatif, rasa ingin tahu tinggi, peduli lingkungan, kerjasama, disiplin, percaya diri, mandiri, tanggungjawab, dan menghargai

\footnotetext{
${ }^{1}$ Murniyetti, Engkizar, and Anwar, "POLA PELAKSANAAN PENDIDIKAN KARAKTER TERHADAP SISWA SEKOLAH DASAR."

${ }^{2}$ Judiani, "Implementasi Pendidikan Karakter di Sekolah Dasar Melalui Penguatan Pelaksanaan Kurikulum."
}

pendapat ${ }^{3}$. Holistik berarti secara keseluruhan. Oleh sebab itu, pendidikan karakter diterapkan secara menyeluruh dan ada hubungannya dengan aspek-aspek kehidupan.

Salah satu pendidikan karakter yang penting adalah sikap disiplin. Kedisiplinan peserta didik awal mulanya tumbuh dan berkembang sejak anak mengenal kehidupan di keluarga. Pada lingkungan keluarga, peserta didik (anak) dilatih mengenai kebiasaan- kebiasaan baik yang berkaitan dengan kepatuhannya terhadap norma, nilai, dan peraturan yang ada. Kedisiplinan yang di bawa dari rumah ini akan menentukan perilaku kedisiplinan peserta didik di sekolah ${ }^{4}$.

Pentingnya mempunyai sikap disiplin karena disiplin mampu menjadikan seseorang menjadi teratur hidupnya. Disiplin adalah tindakan yang menunjukkan perilaku tertib dan patuh pada berbagai peraturan atau ketentuan yang ada ${ }^{5}$. Disiplin ${ }^{6}$ adalah usaha sadar yang dilakukan oleh seseorang untuk mentaati atauran yang sudah ditetapkan. Disiplin juga merupakan serangkaian perilaku seseorang yang menunjukkan ketaatan dan kepatuhan terhadap peraturan, tata tertib, norma kehidupan yang berlaku karena di

${ }^{3}$ Sudarsana, “MEMBENTUK KARAKTER SISWA SEKOLAH DASAR MELALUI PENDIDIKAN ALAM TERBUKA."

4 "Rahmawati, P. (2015). Pengembangan Buku Kendali Kedisiplinan Tata Tertib Siswa SD Negeri Triharjo Sleman. Skripsi. Program Studi.Pdf," 14.

5 Narwanti "Pendidikan Karakter"

6"Jurnal Ilmiah Magister Pendidikan Dasar," 6. 
dorong adanya kesadaran dari dalam dirinya untuk melaksanakan tujuan hidupnya ${ }^{7}$.

Disiplin sangatlah penting dan di butuhan oleh setiap peserta didik. Berbagai manfaat disiplin bagi peserta didik sangatlah terlihat, terutama disiplin yang tumbuh secara sadar akan membentuk sikap perilaku, dan tata kehidupan yang teratur yang nantinya akan menjadikan peserta didik meraih kesuksesan dalam belajarnya. Disiplin yang mantap sudah tertanam dalam diri peserta didik pada hakekatnya akan tumbuh dan terpancar dari hasil kesadaran manusia. Disiplin yang tumbuh dari kesadaran diri, diharapkan akan selalu tertanam dalam setiap diri peserta didik ${ }^{8}$.

Disiplin dalam perilaku peserta didik harus mampu mengatur dalam kegiatan belajar mengajar di kelas atau di sekolah. Apabila peserta didik memiliki sikap disiplin, maka dalam mengikuti proses belajar mengajar di sekolahnya juga akan berjalan dengan baik. Disiplin dapat mengontrol perilaku peserta didik agar nantinya suasana kelas menjadi kondusif dan mendukung tercapainya tujuan pembelajaran9. Tujuan pembelajaran merupakan acuan guru dalam pencapaian yang akan di tempuh oleh peserta didik.

Tujuan pembelajaran seyogyanya harus mampu menggambarkan proses dan hasil belajar yang diharapkan. Bukan hanya mampu menggambarkan hasilnya saja. Dalam kurikulum 2013, antara proses belajar dan hasil belajar harus seimbang. Guru harus mampu untuk mengelola kelas dan mempertahankan kondisi belajar $^{10}$. Kondisi belajar yang dimaksud adalah kondisi guru yang mampu mengatur peserta didik dan segala keperluan

7 "ARDIANSYAH.Pdf," 16.

8 Rohman, "PERAN PENDIDIK DALAM PEMBINAAN DISIPLIN SISWA DI SEKOLAH / MADRASAH," 76. form.].

${ }^{9}$ [CSL STYLE ERROR: reference with no printed

${ }^{10}$ Yuliani, "PENGARUH FASILITAS BELAJAR, PENGELOLAAN KELAS, DAN LINGKUNGAN KELUARGA TERHADAP HASIL BELAJAR EKONOMI MELALUI MOTIVASI BELAJAR SISWA KELAS XI MA AL-ASROR KOTA SEMARANG." belajar demi keefektifan pembelajaran. Nantinya, tujuan pembelajaran diharapkan dapat dicapai oleh peserta didik sesuai dengan kompetensi dasar.

Kompetensi dasar akan tercapai tidak terlepas dari tugas dari seorang guru. Guru harus benar-benar melihat kompetensi dasar yang akan dicapai oleh peserta didik. Dalam pencapaian kompetensi dasar dalam pembelajaran, guru harus menanamkan kedisiplinan peserta didik. Kedisiplinan ini dilakukan dengan tujuan mendidik peserta didik agar nantinya mampu mengatur dirinya sendiri ${ }^{11}$. Saat peserta didik sudah mampu mengatur dirinya sendiri, maka peserta didik akan mengikuti pembelajaran dengan sungguhsungguh demi keberhasilan dirinya sendiri.

Menumbuhkan sikap disiplin peserta didik tentu membutuhkan strategi guru dalam penerapannya. Salah satu strategi guru dalam menumbuhkan disiplin adalah dengan cara manajemen kelas yang baik. Hal ini juga dijelaskan bahwa salah satu peran guru sebagai pendidik adalah sebagai manajer dalam kegiatan manajemen kelas ${ }^{12}$. Menjadi guru yang mampu memanajemen kelas dengan baik dibutuhkan pengalaman dan pengetahuan yang baik pula. Manajemen kelas menjadi faktor penentu keberhasilan pencapaian tujuan pembelajaran termasuk sikap disiplin peserta didik. Dengan begitu guru yang memiliki kemampuan manajemen kelas yang baik akan menjadikan sikap disiplin peserta didik yang baik.

Manajemen kelas adalah keterampilan guru dalam mempersiapkan kondisi yang optimal $^{13}$. Manajemen kelas atau pengelolaan kelas diterapkan agar proses pembelajaran berjalan dengan baik. Tujuan manajemen kelas

${ }^{11}$ Rismayanthi, “OPTIMALISASI PEMBENTUKAN KARAKTER DAN KEDISIPLINAN SISWA SEKOLAH DASAR MELALUI PENDIDIKAN JASMANI OLAHRAGA DAN KESEHATAN."

12 Narwanti, "Pendidikan Karakter"

13 Pamela et al., "KETERAMPILAN GURU DALAM MENGELOLA KELAS." 
adalah menciptakan dan tetap menjaga kondisi kelas agar proses pembelajaran berlangsung tepat pada sasaran ${ }^{14}$. Sasaran yang dimaksud adalah tujuan dari pencapaian belajar. Tujuan akhir dari penerapan manajemen kelas nantinya adalah menjadikan peserta didik mampu menanamkan disiplin pada diri sendiri. Pembentukan sikap agar disiplin ini dilakukan tidak dalam waktu yang singkat, tetapi dilakukan dalam waktu yang lama. Oleh sebab itu, mendidik peserta didik membutuhkan waktu yang lama juga. Guru tidak boleh putus asa dalam mendidik peserta didik menjadi seseorang yang berkarakter.

Keberhasilan manajemen kelas dipengaruhi oleh beberapa faktor. Faktorfaktor tersebut erat kaitannya pada faktor fisik (kondisi kelas), faktor non fisik (sosioemosional) guru, dan kondisi organisasional. Faktor-faktor tersebut menjadi faktor pendukung terhadap tercapainya tujuan pembelajaran ${ }^{15}$. Faktor-faktor yang telah disebutkan, nantinya dijadikan indikator dalam penelitian yang akan peneliti lakukan. Faktor fisik, non-fisik, organisasional menjadi butir-butir pernyataan kemampuan yang harus dimiliki guru.

Peneliti menemukan keadaan lapangan di sekolah dasar negeri 211/IX Mendalo Darat. Temuan yang diperolah di kelas IV sekolah dasar negeri 211/IX Mendalo Darat ternyata memiliki sikap yang sudah mampu bersikap disiplin. Contoh kegiatan disiplin peserta didik yang ditemukan adalah peserta didik di sekolah tersebut sudah mampu mengerjakan tugas sesuai dengan jadwal yang ditetapkan guru. Pada umumnya, semua peserta didik di kelas IV sekolah dasar, sudah mampu untuk mengumpulkan tugas tepat waktu. Saat observasi, peneliti mendapati peserta didik di kelas IV sekolah dasar negeri 211/IX Mendalo Darat, peserta didik menggumpulkan

\footnotetext{
14 "ROFIQ.Pdf."

15 TIM Dosen Administrasi Pendidikan "MANAJEMEN PENDIDIKAN"
}

tugas yang diminta guru selesai pada pukul 09.15 WIB. Ternyata, semua peserta didik mengumpulkan tugas tepat pada waktunya. Beranjak dari kejadian itu, peneliti kemudian menetapkan hal tersebut sebagai hasil observasi awal untuk menindaklanjuti sebab yang terkondisi tersebut.

Peserta didik di sekolah dasar negeri 211/IX Mendalo Darat mengikuti semua arahan dari guru. Peneliti menemukan kondisi nyaman dan peserta didik mengikuti arahan yang diciptakan berasal dari guru kelasnya. Sebab peserta didik mampu bersikap disiplin dikarenakan guru memiliki strategi. Strategi diartikan sebagai proses penentuan rencana yang dilakukan pemimpin untuk mencapai tujuan jangka panjang yang diharapkan ${ }^{16}$. Strategi guru yang tepat akan berdampak positif bagi peserta didik. Tujuan jangka panjang yang disebutkan oleh Umar (2008), dapat disimpulkan bahwa sesorang guru apabila menggunakan strategi yang tepat dan bisa membuat sikap peserta didiknya berubah ke arah yng lebih baik, maka seterusnya peserta didik akan bersikap baik pula.

Berdasarkan uraian masalah tersebut, maka dalam menumbuhkan sikap disiplin peserta didik, guru harus memiliki strategi dalam pembelajaran. Salah satu strategi yang digunakan guru adalah dengan pengoptimalan manajemen kelas di sekolah. Manajemen kelas berhubungan dengan pembentukan karakter peserta didik, terkhusus sikap disiplin. Oleh karena itu, peneliti tertarik sehingga akan melakukan penelitian lebih lanjut dengan judul penelitian "strategi guru sekolah dasar dalam menumbuhkan disiplin peserta didik melalui manajemen kelas".

\section{Metode}

Penelitian ini dirancang untuk mengetahui strategi guru kelas IV di sekolah dasar dalam menumbuhkan disiplin peserta didik melalui manajemen kelas. Penelitian

${ }^{16}$ Umar "Strategi Manajemen" 
ini merupakan penelitian jenis fenomenologi dengan pendekatan kualitatif. Ini merupakan pendekatan kualitatif karena peneliti hanya akan melihat bagaimana strategi yang dilakukan guru dalam menumbuhkan disiplin peserta didik di sekolah dasar. Sedangkan jenis fenomenologi adalah jenis penelitian yang melihat sesuatu berdasarkan fenomenafenomena atau kejadian-kejadian yang terjadi. Fenomena yang dimaksud adalah kejadian yang akan dilihat peneliti benar-benar terjadi di seolah dasar tersebut.

Subjek dalam penelitian ini adalah guru kelas tinggi. Peneliti memilih kelas tinggi karena dianggap sesuai dengan kebutuhan yang dicari peneliti. Kelas tinggi yang terpilih oleh peneliti adalah khusunya kelas IV. Disana pesreta didik kelas IV hanya ada satu rombongan belajar. Subjek merupakan guru kelas IV di sekolah dasar negeri 211/IX Mendalo Darat. Jadi, subjek penelitian ada satu orang guru. guru tersebut berinisial " $R$ ". Penelitian ini dilakukan \pm 4 bulan, yaitu pada tanggal 5 Mei s.d 31 Agustus 2019.

Teknik sampling yang akan digunakan oleh peneliti menggunakan teknik purposive sampling. Peneliti menggunakan teknik ini karena cara pengambilan sampelnya dengan menggunakan pertimbangan - pertimbangan tertentu ${ }^{17}$. Pertimbangan yang dimaksud adalah, bahwa subjek yang digunakan oleh peneliti sudah menerapkan manajemen kelas dengan baik, sehingga tumbuhnya disiplin peserta didik.

Data akan dikumpulkan oleh peneliti menggunakan teknik observasi, wawancara, dan dokumenetasi. Observasi dilakukan setidaknya empat kali pertemuan. Observasi dilakukan dengan menggunakan lembar observasi yang telah divalidasi oleh validator ahli tentang manajemen kelas. Apabila hasil observasi belum menunjukkan atau belum sesuia dengan indikator penelitian,

17 Sugiyono "Penelitian Kuantitatif, Kualitatif, dan R\&D. maka peneliti akan melakukan wawancara langsung dengan subjek penelitian. Kedua teknik tersebut juga akan di dukung dengan pendokumentasian berupa foto-foto, video, dan rekaman wawancara.

Teknik analisis data dilakukan dalam bentuk deskriptif kualitatif. Proses dalam menganalisis data ini menggunakan model kualitatif dari Miles dan Huberman ${ }^{18}$. Langkahlangkah dalam menganalisis data adalah sebagai berikut:

1. Reduksi Data

Pada tahap ini, berarti peneliti memilih data lapangan yang relevan, menafsirkan data atau menyeleksi data kemudian membuat fokus permasalahan yang akan diteliti.

2. Penyajian Data

Data ini akan disajikan secara deskriptif tentang masalah yang ditemukan. Data disajikan dalam teks naratif yang disusun terstruktur.

3. Penarikan Kesimpulan

Menarik kesimpulan setelah melakukan reduksi data dan penyajian data. Menarik kesimpulan berarti mengungkapkan inti dari apa yang sudah ditemukan dan disusun.

\section{Hasil dan Pembahasan}

Hasil penelitian ini akan mendes-kripsikan hasil penelitian yang berupa bagaimana strategi guru kelas tinggi (khusunya kelas IV) di sekolah dasar dalam menumbuhkan disiplin peserta didik. Strategi guru yang dilakukan adalah melalui penerapan manajemen kelas di sekolah dasar negeri 211/IX Mendalo Darat. Peneliti akan mendeskripsikan bahwa strategi yang diterapkan guru sudah berjakan secara maksimal, sehingga berdampak positif bagi peserta didik. Dampak positif dari penerapan manajemen kelas ini adalah menjadikan peserta didik menjadi mempunyai sikap disiplin.

18 Iskandar "Penelitian Kualitatif" 
Untuk mengetahui strategi guru ini, maka peneliti membutuhkan indikatorindikator untuk acuan dalam melakukan penelitian. Indikator yang harus dijadikan acuan adalah indikator manajemen kelas dan indikator disiplin. Indikator manajemen kelas yang digunakan dalam penelitian mengacu pada beberapa faktor, yaitu faktor fisik (kondisi kelas), faktor non fisik (sosio-emosional) dan kondisi organisasional. Indikator tersebut yang digunakan peneliti dalam membuat butir-butir pengamatan dan membuat pertanyaan untuk wawancara. Sedangkan indikator disiplin yang digunakan peneliti ${ }^{19}$.

Indikator pencapaian manajemen kelas peserta didik dalam penelitian dapat dilihat pada tabel.1 sebagai berikut::

\begin{tabular}{|c|c|c|}
\hline No & Indikator & Sub-Indikator \\
\hline \multirow[t]{4}{*}{1} & \multirow[t]{4}{*}{$\begin{array}{l}\text { Faktor Fisik } \\
\text { (Kondisi Kelas) }\end{array}$} & $\begin{array}{l}\text { 1. Ruang tempat } \\
\text { berlangsungnya proses } \\
\text { pembelajaran }\end{array}$ \\
\hline & & $\begin{array}{l}\text { 2. Pengaturan tempat } \\
\text { duduk }\end{array}$ \\
\hline & & $\begin{array}{l}\text { 3. Ventilasi dan } \\
\text { pengaturan cahaya }\end{array}$ \\
\hline & & $\begin{array}{l}\text { 4. Pengaturan } \\
\text { penyimpanan barang- } \\
\text { barang }\end{array}$ \\
\hline \multirow[t]{4}{*}{2} & \multirow{4}{*}{$\begin{array}{l}\text { Faktor Non } \\
\text { Fisik (Kondisi } \\
\text { Sosio- } \\
\text { Emosional) }\end{array}$} & 1. Tipe kepemimpinan \\
\hline & & 2. Sikap guru \\
\hline & & 3. Suara guru \\
\hline & & $\begin{array}{l}\text { 4. Pembinaan hubungan } \\
\text { baik }\end{array}$ \\
\hline \multirow[t]{3}{*}{3} & \multirow[t]{3}{*}{$\begin{array}{l}\text { Kondisi } \\
\text { Organisasional }\end{array}$} & $\begin{array}{l}\text { 1. Guru berhalangan } \\
\text { hadir }\end{array}$ \\
\hline & & $\begin{array}{l}\text { 2. Masalah antar peserta } \\
\text { didik }\end{array}$ \\
\hline & & 3. Kegiatan Rutin \\
\hline
\end{tabular}

Tabel.1 Kisi-Kisi Pedoman dalam Manajemen Kelas

Sumber: TIM Dosen Administrasi Pendidikan (2009: 111-114)

Dalam melaksanakan observasi tentang manajemen kelas guru, peneliti menyiapkan 15 butir pengamatan. Observasi dilaksanakan beberapa kali. Lembar observasi digunakan

19 “Kementerian Pendidikan Dan Kebudayaan 2016. Penilaian Untuk Sekolah Dasar (SD).Pdf." setalah ada validasi instrumen oleh validator ahli. Observasi ini digunakan peneliti untuk mengumpulkan data-data tentang apa saja strategi yang digunakan guru dalam menumbuhkan disiplin peserta didik. Karena ada beberapa pernyataan observasi yang belum terjawab, maka peneliti menyiapkan beberapa butir pertanyaan untuk wawancara, dan difungsikan sebagai langkah lanjutan agar mendapat hasil penelitian yang lengkap dan sesuai dengan apa yang dibutuhkan oleh peneliti.

Keberhasilan manajemen kelas guru tersebut dilihat dari pencapaian indikator manajemen kelas yang dilakukan guru. Kemudian, peneliti akan mendeskripsikan dampak dari penerapan manajemen kelas yang ternyata mampu membuat peserta didik bersikap disiplin. Keberhasilan kedua aspek tersebut dapat dideskripsikan sebagai berikut:

\section{Faktor Fisik (Kondisi Kelas)}

Kondisi fisik (kondisi kelas) ini berhubungan dengan bagaimana keadaan atau kondisi ruang kelas. Di ruang kelas IV, hasil penelitian menunjukkan bahwa guru telah mengatur ruang kelas dengan baik. guru sudah memasang hiasan-hiasan dinding di ruang kelas, sehingga membuat peserta didik betah dan nyaman berada di dalam kelas. Ini ternyata mengakibatkan peserta didiknya menjadi disiplin dalam masuk kelas. Tidak terlambat masuk kelas. Mereka masuk kelas selalu tepat waktu, karena ruangan tempat belajarnya nyaman. Guru kelas IV juga memberikan waktu dalam pengerjaaan latihan, sehingga peserta didik menjadi disiplin dalam mengatur waktu. Guru meletakkan jam dinding kelas agar peserta didik menjadi tau kapan waktunya belajar dan kapan waktu untuk bermain. Mereka juga tahu kapan waktu yang dibutuhkan dalam mengerjakan tugas dan mengumpulkan tugasnya. Karena itualah, 
peserta didik mau mengumpulkan tugas sesuai waktu yang telah ditentukan guru.

Guru selalu mengatur tempat duduk peserta didik secara bervariasi dan berkelompok, agar peserta didik tidak bosan selama proses pembelajaran. Semua peserta didik diberi kesempatan untuk duduk dengan posisi yang berbeda-beda namun tetap menghadap ke arah papan tulis. Ternyata, karena peserta didik duduk secara berkelompok, ini mengakibatkan peserta didik mudah dalam bekerjasama dalm mengerjakan tugas. Kerjasama ini dapat membuat peserta didik menjadi disiplin dalam mengerjakan tugas. Mereka terlihat bersemangat dalam mengerjakan tugas, berlomba-lomba untuk cepat menyelesaikan tugas dengan kelompok lain.

Guru mengatur ventilasi dan pengaturan cahaya dengan baik, memasang gorden sesuai posisi yang tepat, menghidupkan lampu jika pencahayaan di dalam kelas kurang. Pencahayaan yang baik yang dilakukan oleh guru kelas IV mengakibatkan peserta didik menjadi disiplin dalam merawat gorden dan mengelap kaca jendela. Mereka rajin membersihkan jendela dengan bersama-sama. Mereka merawat fasilitas sekolah dengan baik.

Guru juga menghimbau peserta didik untuk menyimpan alat-alat sekolah setelah digunakan, dan mengembalikan serta menyimpan peralatan kelas di tempat yang telah disediakan. Hal ini membuat peserta didiknya tidak membiarkan peralatan belajarnya berantakan. Mereka selalu menyimpan kembali peralatan belajar di dalam tas sekolahnya. Ini membuktikan bahwa peserta didik di kelas IV mampu bersikap disiplin untuk kepentingan pribadiya.

Kedisiplinan peserta didik sangat erat kaitannya dengan kerajinan peserta didik. Selain yang telah dijelaskan, guru juga membuat daftar piket kelas dengan rapi. Guru selalu menghimbau peserta didik untuk menjaga kondisi kelas agar tetap rapi dan bersih. Guru dan perserta didik bersama-sama membersihkan lingkungan kelas dari sampahsampah. Karena hal tersebut, kondisi kelas IV selalu terlihat bersih dari sampah, karena semua anggota kelas IV bertanggungjawab atas kelasnya, terutama yang piket. Petugas piket selalu melaksankan tugas piketnya dengan baik. peserta didik menjadi lebih disiplin, karena menyukai hal yang indah dan bersih, dan mau melaksankan tanggungjawab sesuai aturan dan kesepakatan bersama. Karena peran guru mempengaruhi kedisiplinan peserta didik, maka guru juga ikut serta dalam membuat peserta didik menjadi disiplin. Dari penjelasan tersebut membuktikan bahwa peserta didik menjadi disiplin karena campur tangan guru untuk ikut menjaga kebersihan ruang kelas.

\section{Faktor Non Fisik (Kondisi Sosio-Emosional)}

Faktor non fisik (kondisi sosioemosional) ini berhubungan dengan sikap sosial dan bagaimana emosi guru dalam mengajar atau menghadapi peserta didik. Hasil penelitian menunjukkan bahwa guru telah menjadi guru melaksanakan secara demokratis. Guru menunjukkan sikap berwibawa, sabar, dan tetap menjadi guru yang baik bagi peserta didik. Sikap guru tersebut membuat peserta didik menjadi mentaati semua perintah guru, mau mengikuti kegiatan belajar mengajar dengan baik, tertib dalam melaksanakan tugas yang diberikan oleh guru.

Selain itu, peserta didik mau mengikuti semua peraturan yang sudah ditetapkan oleh sekolah. Aturan tersebut mulai dari memakai pakaian sesuai dengan ketentuan, membuang sampah pada tempatnya, dan tidak merusak fasilitas sekolah. Karena sikap guru yang adil dengan semua peserta didik, peserta didik di kelas IV mau mengikuti semua aturan guru. Mereka tidak ada yang membantah perkataan guru dan segan saat bertemu guru.

Guru memainkan intonasi suara untuk menarik perhatian peserta didik. Guru mengetahui kapan harus memakai nada rendah 
atau nada tinggi saat berbicara dengan peserta didik. Di kelas IV gurunya sudah berbicara dengan jelas dan tegas saat menerangkan materi ajar. Hal ini juga ternyata mampu membuat peserta didik menjadi segan terhadap guru. Peserta didik merasa nyaman mendengarkan suara guru. intonasi yang diperdengarkan jelas, sehingga peserta didik mudah dalam mendengarkan perkataan guru dan menyerap materi ajar yang disampaikan. Apabila diberi kesempatan untuk bertanya, peserta didik pun mau bertanya tanpa rasa takut.

Guru mampu membina hubungan yang baik dengan peserta didik, sehinga peserta didik senang dan gembira melaksanakan proses belajar dengan guru tersebut. Guru mampu memberi tauladan yang baik bagi peserta didik. Sikap guru tersebut, tidak membeda-bedakan antara peserta didik yang satu dengan lainnya. Hal ini mengakibatkan peserta didik merasa adil, dan mereka patuh terhadap guru. Mereka tidak membantah guru, dan menghormati guru.

\section{Kondisi Organisasional}

Kondisi organisasional berhubungan dengan hubungan antara guru dengan peserta didik. Guru meminta izin jika berhalangan hadir ke sekolah, dan meminta guru pengganti untuk mengajar agar peserta didik tetap melakukan kegiatan belajar mengajar. Perilaku guru ini mengajarkan peserta didik untuk selalu izin atau memberikan kabar saat berhalangan hadir. Begitu pula dengan peserta didik, saat observasi peneliti mendapati peserta didik yang berhalangan hadir. Dia mengirimkan surat karena sedang sakit. Selain itu, ada juga yang sekedar menelfon guru karena berhalangan hadir. Dari uraian tersebut, ternyata peserta didik akan mencontoh perilaku gurunya. Peserta diidk menjadi taat akan aturan.

Apabila terjadi masalah antar peserta didik, guru ikut serta dalam memberikan solusi kepada peserta didik, mau mendengarkan peserta didik. Guru menjadi penengah bagi permasalahn yang terjadi antar peserta didiknya dan guru juga menghimbau kepada peserta didik agar mengkuti upacara rutin sekolah dan upacara hari-hari besar sebagai bentuk dalam menumbuhkan kedisiplinanya. Hal tersebut mengakibatkan peserta didiknya menjadi taat terhadap guru. karena guru dianggap bisa mengatasi semua masalah yang terjadi dengan peserta didik. Guru akan dianggap sebagai orang yang bisa menyelesaikan permasalahan peserta didik.

Guru meminta peserta didik untuk mengikuti kegiatan rutin yang diselenggarakan oleh sekolah. Kegiatan tersebut berupa pembiasaan atau literasi. Misalnya pada hari Senin mengikuti upacara bendera, pada hari Selasa mengikuti kegiatan membaca lancara, pada hari Rabu nya mengikuti kegiatan menyanyikan lagu-lagu wajib nasional, pada hari Kamis mengikuti kegiatan menghafal perkalian, pada hari Jum'at mengikuti kegiatan Yasinan, dan pada hari Sabtu mengikuti kegiatan Senam sehat.

Peserta didik mau mengikuti kegiatan tersebut dengan semangat, sehingga mereka datang lebih awal agar bisa mengikuti pembiasaan tersebut. Selain itu, pesreta didik menjadi disiplin dalam memanajemen waktu. Meraka harus datang 15 menit lebih awal sebelum kegiatan belajar mengajar dimulai. Peneliti melihat peserta didiknya menjadi disiplin waktu. Mereka hadir ke sekolah lebih awal dan mau mentaati aturan-aturan sekolah. Secara umum siswa kelas IV mampu menghargai waktu dan mengelola waktu dengan baik.

Apabila guru yang piket pada hari itu terlambat, mereka tetap bersiap-siap untuk mengikuti kegiatan. Misalnya saat kegiatan membaca, meskipun gurunya belum datang, mereka sudah membawa buku bacaan untuk di baca. Hal itu menjadikan peserta didik mempunyai kebiasan yang baik. Program sekolah juga berjalan sesuai keinginan. 
Berdasarkan uraian tersebut, peneliti menyimpulkan bahwa guru di sekolah dasar negeri 211/IX Mendalo Darat sudah melaksanakan manajemen kelas dengan baik. manajemen kelas yang baik ini dilihat karena guru sudah memanajemen kelas sesuai indikator keberhasilan manajemen kelas. Manajemen kelas yang dilaksanakan oleh guru kelas IV tersebut ternyata mampu membuat peserta didik bersikap disiplin. Hal tersebut dibuktikan dari perilaku peserta didiknya terhadap guru. Aspek disiplin yang ditunjukkan guru tersebut ternyata diakibatkan karena strategi guru, yaitu manajemen kelas yang maksimal.

Peserta didik di kelas IV sekolah dasar negeri 211/IX Mendalo Darat sudah berperilaku sesuai norma-norma yang ada, meliputi: peserta didik memperhatikan guru saat menjelaskan materi pelajaran, menjaga kebersihan kelas, membuang sampah pada tempatnya, menghargai guru, meminta izin kepada guru saat berhalangan hadir ke sekolah, mentaati semua peraturan yang berlaku di sekolah, dan lain-lain. Karena dampak yang positif itulah, peneliti dapat memberi kesimpulan bahwa strategi guru dalam menumbuhkan disiplin dapat diatasi dengan cara manajemen kelas yang maksimal.

\section{Daftar Pustaka}

Ardiansyah, H. (2013). FAKTOR-FAKTOR YANG MEMPENGARUHI DISIPLIN BELAJAR PESERTA DIDIK KELAS XII JURUSAN ADMINISTRASI PEKANTORAN DI SMK NU 01 KENDAL TAHUN PELAJARAN 2012/2013 (Doctoral dissertation, Universitas Negeri Semarang).

Iskandar. 2009. Metodologi Penelitian Kualitatif. Jakarta: GP Press

Judiani,S. (2010). Implementasi pendidikan karakter di sekolah dasar melalui penguatan pelaksanaan kurikulum.Jurnal pendidikan dan kebudayaan, 16(9), 280-289.
Murniyetti, M., Engkizar, E., \& Anwar, F. (2016). Pola pelaksanaan pendidikan karakter terhadap peserta didik sekolah dasar. Jurnal Pendidikan Karakter, 6(2).

Narwanti S.2013. Pendidikan Karakter. Yogyakarta: Familia.

Putra, E. A., Djuwita, P., \& Juarsa, O. (2019). Keterampilan Guru Mengelola Kelas pada Proses Pembelajaran untuk Menumbuhkan Sikap Disiplin Belajar Peserta didik (Studi Deskriptif Kelas IVB SD Negeri 01 Kota Bengkulu). Jurnal Pembelajaran dan Pengajaran Pendidikan Dasar, 2(1), 35-46.

Rahmawati, P. 2015. Pengembangan Buku Kendali Kedisiplinan Tata Tertib Siswa SD Negeri Triharjo Sleman. Program Studi Pendidikan Guru Sekolah Dasar. Universitas Negeri Yogyakarta.

Rismayanthi, C. (2011). Optimalisasi PembentukanKarakterdanKedisiplinan Peserta didik Sekolah Dasar melalui Pendidikan Jasmani Olahraga dan Kesehatan. Jurnal Pendidikan Jasmani Indonesia, 8(1).

Rofiq, A. (2009). Pengelolaan kelas. Malang: Direktorat Jendral PMPTK.

Rohman, F. (2018). Peran Pendidik dalam Pembinaan Disiplin Peserta didik di Sekolah/Madrasah. Ihya al-Arabiyah: Jurnal Pendidikan Bahasa dan Sastra Arab, 4(1).

Sudarsana, I. K. (2016). Membentuk Karakter Peserta didik Sekolah Dasar melalui Pendidikan Alam Terbuka. Prosiding Nasional.

Sugiyono. 2016. Metode Penelitian Kuantitatif, Kualitatif dan RED. Bandung: Alfabeta

TIM Dosen Administrasi Pendidikan.2009. Manajemen Pendidikan. Bandung: Alfabeta.

Umar. 2008. Strategi Manajemen. Jakarta: PT. Gramedia Pustaka Utama.

Wiyani N.A. 2013. Manajemen Kelas "Teori dan Aplikasi untuk Menciptakan Kelas yang 
46| Elementirly Vol. 6 No. 1, January-June 2020

Kondusif". Jogjakarta: Ar-Ruzz Media.

Wuryandani, W., Maftuh, B., \& Budimansyah, D. (2014). Pendidikan Karakter Disiplin di Sekolah Dasar. Jurnal Cakrawala Pendidikan, 33(2).

Yuliani, P. (2014). Pengaruh fasilitas belajar, pengelolaan kelas, dan lingkungan keluarga terhadap hasil belajar ekonomi melalui motivasi belajar peserta didik Kelas XI MA AL-Asror Kota Semarang. Economic Education Analysis Journal, 3(1). 